\title{
Finansal Kiralama Şirketlerinde Riskten Korunma Muhasebesi
}

\author{
Birsel SABUNCU*
}

\section{ÖZET}

Dünya ekonomisinde çok fazla, ülkemizde de gün geçtikçe artan finansal kiralama faaliyetleri piyasayl tamamlayıcı rol üstlenmektedir. Finansal kiralama faaliyetlerini yürüten finansal kiralama şirketleri ekonomide finansal olarak yatırm ve üretim faaliyetlerini arttırmak isteyen şirketlere alternatifler sunmaktadırlar.

Finansal kiralama şirketlerinin kuruluşu Bankacılık Düzenleme ve Denetleme Kurumu'nun iznine bağll olup, Türk Ticaret Kanunu'nunda yer alan anonim şirketlerin kurulmasina ilişskin hükümler uygulanmaktadir. Finansal kiralama şirketleri, işlemlerin muhasebeleştirilmesi ve finansal tablolarının hazırlanmasinda Türkiye Muhasebe Standartlart ve Türkiye Finansal Raporlama Standartların'dan ve Bankacılık Düzenleme ve Denetleme Kurumu tarafindan düzenlenmiş olan Tekdüzen Hesap Planı'ndan yararlanmaktadır.

Bu çalışmanın amacı, Türkiye Muhasebe Standartlarına tabi olmasına rağmen muhasebe kayıtlarında ayrı bir hesap planının kullanıldiğ finansal kiralama sirketlerinin riskten korunma muhasebesi uygulamalarına yer verilerek literatüre katkı sağlamaktır. Örnek uygulamalarda, riskten korunma aracından ve riskten korunma konusu kalemden kaynaklanan kâr veya zararların finansal riskten korunma muhasebesi uygulaması sayesinde aynı dönemde muhasebeleştirildiği gözlemlenmektedir.

Anahtar Kelimeler: Finansal kiralama şirketi, Türkiye Muhasebe Standard, Finansal riskten korunma muhasebesi

JEL Sinıflandırması: M40, M41

\section{Hedge Accounting in Financial Leasing Companies \\ ABSTRACT}

Financial leasing operations mostly seen in global economy and increasing day by day in our country have assumed a complementary role for the market. Financial leasing companies that carry out financial leasing operations provide alternatives to the companies that demand to increase their financial investment and production activities.

The establishment of financial leasing companies is subject to the permit of the Banking Regulation and Supervision Agency and the provisions of the Turkish Commerce Code concerning joint-stock corporations. Financial leasing companies make use of Turkish Accounting Standards and Turkish Financial Reporting Standards and Uniform Accounting Plan regulated by the Banking Regulation and Supervision Agency for accounting transactions and preparation of financial statements.

The objective of this study is to provide contribution to the literature by describing hedge accounting for the financial leasing companies where a separate accounts chart is used in their accounting plan although they are subject to Turkish Accounting Standards. It is observed from the samples that profit or loss resulting from hedge accounting item and hedge accounting instrument may be recognized in the same period.

Keywords: Financial leasing company, Turkish Accounting Standards, Hedge Accounting Jel Classification: M40, M41

\footnotetext{
*Yrd. Doç. Dr Birsel Sabuncu, Pamukkale Üniversitesi, Honaz Meslek Yüksekokulu, bsabuncu@pau.edu.tr
} 


\section{GİRIŞ}

Finansal kiralama şirketleri faturaya dayalı işlem yapmak zorunda olduklarından yapmış oldukları bütün işlemler ekonominin kayıt içine alınmasında önemli bir destek sağlamaktadır. Ekonomide bu kadar etkili olan bu şirketler, ülkemizde başlangıçta çoğu bankaların yan kuruluşu olarak faaliyetine devam etmekte olup, 2010 y1lından itibaren sayılarında artış olmaya başlamıştır. Finansal kiralama işlemlerinin kayıt altında gerçekleştirilmesi imkanını sağlayan finansal kiralama şirketlerinin sayıca artması ülke ekonomisine büyük katkı sağlamaktadır.

Finansal kiralama şirketleri, girişimciler için alternatif olarak gün geçtikçe daha çok tercih edilen boyuta gelmiş olup, ekonomideki düzenleyici rolleri önemsenmektedir. $\mathrm{Bu}$ gelişmeler sürecine bağlı olarak finansal kiralama şirketlerinin muhasebe uygulamaları önemli hale gelmiştir.

Türkiye Muhasebe Standartlarının uygulamaya geçişi ile birlikte riskten korunma muhasebesi gündemimize oturmuş ve bu konuda çalışmalar yapılmaya başlanmıştır. Riskten korunma muhasebesinin uygulanması isteğe bağlı olup, şirketler isterlerse riskten korunma muhasebesini uygulamaktadır.

Riskten korunma muhasebesinin uygulanmamas1, riskten korunan kalem ve korunma aracına ait kâr veya zararın farklı dönemlerde gelir tablosunda raporlanması sonucu kârın dönemler itibariyle dalgalanmasına neden olmaktadır. Kârın dönemler itibariyle dalgalanması, riskten korunma stratejisinin faydalarına karşı olumsuz bir durum ortaya çıkarabilmektedir. Bu durumda riskten korunma muhasebesi uygulanarak bu dalgalanma önlenebilmektedir.

Demir (2009), “TFRS/UFRS Kapsamında Finansal Araçlar” ile Örten, Kaval ve Karapınar (2014), "Türkiye Muhasebe -Finansal Raporlama Standartları Uygulama ve Yorumları" adlı kitaplarında, riskten korunma muhasebesi ile ilgili örnek uygulamalar yer almaktadır.

Bline, Ficher ve Skekel (2001), “Advanced Accountig”, Ramirez (2007), Accounting For Derivatives. Advanced Hedging Under IFRS” ve Beams, Anthony, Bettinhous ve Smith (2012) “Advanced Accountig” isimli kitaplarında riskten korunma muhasebesi ile ilgili örnekler ve muhasebe kayıtları yer almaktadır.

Çalışmada, Türkiye Muhasebe Standartlarına tabi olmasına rağmen muhasebe kayıtlarında ayrı bir hesap planının kullanıldığı finansal kiralama şirketlerinin riskten korunma muhasebesi uygulamaları örneklerle açıklanmaktadır. 2013 yılında Bankacılık Düzenleme ve Denetleme Kurumu tarafından yayımlanan hesap planındaki hesaplar kullanılarak muhasebe kayıtları gerçekleştirilmiştir. Finansal kiralama şirketlerinin faaliyetlerinin esasını oluşturan "TMS 17 Finansal Kiralama Standardı"nın uygulandığı işlemlerde riskten korunma uygulanmamaktadır. Gerçeğe uygun değer riskinden korunmada işlem süresince değerleme farkları kâr veya zarar hesaplarına, nakit akış riskinden ve net yatırım riskinden korunmada işlem süresince etkin kısımlar diğer kapsamlı gelirde, etkin 
olmayan kısımlar ise kâr veya zarar hesaplarına kaydedilmektedir. Finansal riskten korunma muhasebesi uygulamas1, riskten korunma aracindan ve riskten korunma konusu kalemden kaynaklanan kâr veya zararların aynı dönemde muhasebeleştirilmesini sağlamaktadır.

\section{FINANSAL KİRALAMA ŞİRKETLERİ}

Finansal kiralama şirketleri, sermayelerini yatırım ve üretimde kullanmak isteyen yatırımcılara önemli finansal destek sağlamaktadır. Ülkemizde Bankacılık Düzenleme ve Denetleme Kurumu (BDDK) bünyesindeki yönetmelik ve tebliğlerle çalışma esasları belirlenen kiralama şirketleri faaliyetleri hızla artış göstermektedir.

6361 say1lı 13.12.2012 tarihli Resmi Gazete'ye göre finansal kiralama şirketleri, yalnızca anonim şirket olarak kurulabilmektedir (Köksal ve Beller, 2013: 152).

Finansal kiralama şirketlerinin en önemli finansman kaynakları özkaynaklar ve otofinansmandır. Finansal kiralama şirketlerinin fon kaynakları (Ceylan, 2003: 139):

a) Özkaynak,

b) Otofinansman,

c) Yurt içi ve yurt dışı yabancı kaynaklar.

Finansal kiralama şirketleri, işlemlerini muhasebeleştirmede, finansal tablolarının hazırlanmasında ve denetiminde 26/9/2011 tarihli ve 660 sayılı Kamu Gözetimi, Muhasebe ve Denetim Standartları Kurumunun Teşkilat ve Görevleri Hakkında Kanun Hükmünde Kararname çerçevesinde gerçekleştirmektedirler. Fakat, finansal kiralama şirketleri faaliyetlerini muhasebeleştirirken Bankacılık Düzenleme ve Denetleme Kurumu (BDDK) tarafından yayımlanmış olan Tekdüzen Hesap Planı’nı kullanmaktadırlar.

Ekonomide düzenleyici rol üstlenen finansal kiralama şirketlerinin muhasebe uygulamalarında kullanılan Tekdüzen Hesap Planı'nda 2007 yılından değişiklik gerçekleşmiştir. 17 Mayıs 2007 tarihinde 26525 sayılı Resmi Gazete'deki tebliğde finansal kiralama şirketlerinin kullanacağı Tekdüzen Hesap Planı yayımlanmış ve yürürlüğe girmiştir. $\mathrm{Bu}$ tarihe kadar finansal kiralama şirketleri tarafından Muhasebe Sistemi Uygulama Genel Tebliği'nde yayımlanmış olan Tekdüzen Hesap Planı kullanılmaktadır. Daha sonra, 24 Aralık 2013 tarihinde 28861 sayılı Resmi Gazete'de "Finansal kiralama, Factoring ve Finansman şirketlerince uygulanacak Tekdüzen Hesap Planı ve İzahnamesi Hakkında Tebliğ" yayımlandıktan sonra, finansal kiralama şirketleri muhasebe uygulamalarını bu tebliği doğrultusunda gerçekleştirmektedir.

\section{FINANSAL RISSKTEN KORUNMA MUHASEBESI (HEDGE ACCOUNTING)}

Bir finansal riskten korunma aracı ve başka bir finansal araç arasında bir ilişki bulunduğunda ve koşullar oluşturulduğunda TMS 39'a göre finansal riskten korunma muhasebesi uygulanması gerekmektedir. Finansal riskten korunma araçları genellikle türev finansal araçlardır (Demir, 2009: 128). 
Türev finansal araçlar genellikle forward, futures, opsiyon ve swap sözleşmelerinden oluşmaktadır.

Forward, vadesi, miktarı ve fiyatı önceden belirlenmiş bir malın, menkul kıymetin ileri tarihte teslimin öngören anlaşmalardır. Futures, bir malın, menkul kıymetin anlaşmanın yapıldığ 1 tarihte belirlenen fiyattan gelecekte belirlenen tarihte teslimini içeren sözleşmeler olup, organize borsalarda satılmaktadır (Alphan, 1999: 2-3).

Opsiyon, sözleşmeyi satın alan tarafa seçim hakkı veren, sözleşmeyi satan tarafa da yükümlülük veren anlaşmalardır. Swap sözleşmeleri, tarafların faizi ya da döviz cinsini değiştirmek suretiyle yaptıkları takas sözleşmeleridir (Demir, 2009: 112-113).

Finansal riskten korunma muhasebesi tüm şirketler tarafından, aşağıdaki durumlar hariç olmak üzere uygulanabilmektedir (TMS 39: Madde 2) :

(a) İş ortaklıklarındaki yatırımların hükümlerine göre muhasebeleştirilen bağlı ortaklıklar, iştirakler ve iş ortaklıklarındaki paylar.

(b) “TMS 17 Kiralama İşlemleri” Standardının uygulandığı kiralama işlemlerindeki hak ve yükümlülükler. Ancak: (i)Kiraya veren tarafından muhasebeleştirilen kira alacakları bu standardın finansal durum tablosu (bilanço) dışı bırakma ve değer düşüklüğüne ilişkin hükümlerine tabidir. (ii) Kiralayan tarafından muhasebeleştirilen finansal kiralama borçları bu standardın finansal durum tablosu (bilanço) dışı bırakma hükümlerine tabidir. (iii) Kiralama işlemlerinde saklı türev ürünler, bu standardın saklı türev ürünlerle ilgili hükümlerine tabidir.

(d) Şirketler tarafından ihraç edilen, öz kaynağa dayalı finansal araç tanımına giren finansal araçlar.

(e) Sigorta sözleşmesinden veya TFRS 4 kapsamına giren bir sözleşmeden kaynaklanan hak ve yükümlülükler.

(f) Gelecekteki bir tarihte TFRS 3 İşletme Birleşmeleri Standardı kapsamında işletme birleşmesine yol açacak olan forward sözleşmeleri.

\subsection{Finansal Riskten Korunma Çeşitleri}

Finansal riskten korunma, çeşitlerine göre a) Gerçeğe uygun değerindeki değişimlere, b) nakit akışlarındaki değişimlere ve c) yabancı yatırımların değerlerindeki değişimlere karşı korumayı içermektedir (Demir, 2009: 131).

Gerçeğe uygun değer riskinden korunma, bir varlığın gerçeğe uygun değerinde meydana gelen, belirli bir risk unsuru ile ilişkilendirilebilen, kâr veya zararı etkileyebilecek nitelikteki değişikliklere karşı gerçekleştirilen bir finansal riskten korunma işlemidir. Nakit akış riskinden korunma, bir varlığın gerçekleşme ihtimali yüksek tahmini bir işleme ilişkin belirli bir riskle ilişkilendirilebilen ve net kâr veya zararı etkileyebilen nitelikteki nakış akışı değişikliklerinden korunmak için gerçekleştirilen bir riskten korunma işlemidir. Net yatırım riskinden korunma ise “TMS 21 Kur Değişimin Etkileri' Standardı'nda yer almaktadır (TMS 39: Madde 86). 


\subsection{Finansal Riskten Korunma Muhasebesi Uygulama Koşulları}

Finansal riskten korunma muhasebesinin uygulanmamas1, riskten korunan kalem ve korunma aracına ait kâr veya zararın farklı dönemlerde gelir tablosunda raporlanması sonucu kârın dönemler itibariyle dalgalanmasına neden olmaktadır. Kârın dönemler itibariyle dalgalanması, riskten korunma stratejisinin faydalarına karşı olumsuz bir durum ortaya çıkarabilmektedir. Bu durumda riskten korunma muhasebesi uygulanarak bu dalgalanma önlenebilmektedir. Finansal riskten korunma muhasebesinin uygulanması isteğe bağl1 bırakılmıştır. Fakat, uygulama kararı alan şirketler için yerine getirilmesi gereken şartlar söz konusudur. Şirketler, isterlerse riskten korunma muhasebesini uygulamaktadır.

Finansal riskten korunma muhasebesinin uygulanması için; a) finansal riskten korunma işleminde bulunmasına neden olan risk yönetimi hedef ve stratejisinin resmi bir tanımının bulunması ve belgeye dayanması, b) riskten korunma işleminin, korunmak istenen risk ile ilişkili gerçeğe uygun değerdeki veya nakit akışlarındaki değişiklikleri dengelemede oldukça etkin olması, c) nakit akış riskinden korunma işlemleri için, finansal riskten korunma işleminin konusunu teşkil eden tahmini işlemin gerçekleşme ihtimalinin yüksek olması ve nakit akışlarındaki değişikliklerin kâr veya zararı etkileyebilecek nitelikte olması gerekir d) etkinliğin güvenilir bir şekilde ölçülebilmesi e) etkinliğin \%80-\%125 aralığında olması ve ilgili finansal riskten korunma ilişkisine ilişkin belgelendirilmiş risk yönetim stratejisi ile tutarlı olması beklenir (TMS 39: Madde 88).

Riskten korunma muhasebesinin uygulanabilmesi için tüm koşulların yerine getirilmesi gerekmektedir. Koşullardan biri bile yerine getirilmediği takdirde riskten korunma muhasebesi uygulanamamaktadır.

Şirket aşağıdaki durumlardan birinin oluşması durumunda, finansal riskten korunma muhasebesini uygulamaya son verir (TMS 39: Madde 91):

(a) Finansal riskten korunma aracinın vadesinin dolması, satılması, sonlandırılması veya kullanılmasi.

(b) Finansal riskten korunma muhasebesine ilişkin gerekli koşulları sağlayamaz duruma gelmesi veya

(c) Şirketin ilgili işleme ilişkin sınıflandırmayı/düzenlemeyi iptal etmesi.

\section{3. Gerçeğe Uygun Değer Riskinden Korunma Muhasebesi}

Gerçeğe uygun değer riskinden korunma işleminin koşulları dönem boyunca sağlaması durumunda aşağıdaki şekilde muhasebeleştirilir (TMS 39: Madde 89):

(a) Finansal riskten korunma aracının gerçeğe uygun değerinin yeniden ölçülmesinden kaynaklanan kazanç veya kayıplar, kâr ya da zararda muhasebeleştirilir, 
(b) Finansal riskten korunma konusu kalemden kaynaklanan ve korunulan riskle ilişkilendirilebilen kazanç veya kayıp, finansal riskten korunma konusu kalemin defter değerine yansıtılır ve kâr veya zararda muhasebeleştirilir.

\section{4. Nakit Akış Riskinden Korunma Muhasebesi}

Nakit akış riskinden korunma işleminin muhasebeleştirilmesinde, koşulların sağlaması durumunda finansal riskten korunma aracından kaynaklanan kazanç veya kayıpların etkin olan kısmı özkaynaklarda yani diğer kapsamlı gelirler içersinde muhasebeleştirilirken, kazanç veya kaybın etkin olmayan kısmı gelir tablosu hesaplarında muhasebeleştirilir (TMS 39: Madde 95).

Nakit akış riskinden korunma muhasebesi uygulayan firma işlemin sonlanması durumunda, aşağıdaki seçeneklerden birini uygular (TMS 39: Madde 98):

-Diğer kapsamlı gelir içerisinde yani özkaynaklarda muhasebeleştirilmiş olan kazanç veya kayıpları, elde edilen varlığın veya üstlenilen borcun kâr veya zararı etkilediği dönem veya dönemlerde yeniden sınıflandırma düzeltmesi olarak kâr veya zarar içerisinde yeniden siniflandırılmakta veya,

-Diğer kapsamlı gelir içerisinde, özkaynak hesaplarında muhasebeleştirilmiş bulunan kazanç veya kayıpları iptal ederek varlık veya borcun ilk maliyetine veya defter değerine dahil edilmektedir.

\section{5. Net Yatırım Riskinden Korunma Muhasebesi}

Yurtdışındaki şirkette bulunan net yatırım riskinden korunma amaçlı işlemler, nakit akış riskinden korunma işlemlerine benzer olarak muhasebeleştirilir (Demir, 2009: 145-146):

(a) Finansal riskten korunma aracından kaynaklanan kazanç veya kaybın etkin olan kısmı özkaynaklar içerisinde muhasebeleştirilir,

(b) Finansal riskten korunma aracından kaynaklanan kazanç veya kaybın etkin olmayan kısmı gelir tablosu hesaplarında muhasebeleştirilir.

TMS 21 standardının 32. maddesinde belirtildiği üzere, işletmenin yurt dışındaki işletmedeki net yatırımın bir parçası olması durumunda, ortaya çıkan kur farkları başlangıçta özkaynaklarında ayrı bir unsur olarak muhasebeleştirilmekte ve net yatırımın elden çıkarılması ile birlikte kâr veya zararda muhasebeleştirilmektedir. Ayrıca, standardın 48. maddesinde, yurt dışındaki işletmenin elden çıkarılmasında özkaynakların ayrı bir unsuru olarak kaydedilmiş olan ve bu işletmeye ait birikmiş kur farkları, kâr ya da zarar olarak finansal tablolarda yansıtılmalı şeklinde ifade edilmektedir. 


\section{4. ÖRNEK UYGULAMA}

Finansal kiralama şirketleri tarafından muhasebe uygulamalarında yararlanılacak Tekdüzen Hesap Planı, 24.12.2013 tarih 28861 sayılı Resmi Gazete'de yayımlanan tebliğ ile ayrıntılı olarak yer almaktadır. Bankacılık Denetleme ve Düzenleme Kurumu (BDDK)'nun yayımladığı Tekdüzen Hesap Planı, aşağıda belirtilen gruplardan oluşur (BDDK, 2013);

0 Dönen Değerler

1 Ana Faaliyetlerden Alacaklar

2 Yatırım Amaçlı Değerler ve Diğer Aktifler

3 Bankalardan Kullanılan Krediler ve Diğer Yabancı Kaynaklar

4 Özkaynaklar

5 Ana Faaliyet Gelirleri

6 Finansman Giderleri

7 Faaliyet Dışı Gelirler

8 Faaliyet Giderleri ve Diğer Giderler

9 Bilanço Dişı Hesaplar

Her grup içerisinde yer alan hesaplar, Türk parası ve yabancı para olarak ikiye ayrılmıştır. Defteri kebir hesaplarından son hanesi çift numaralı olanlar Türk parası, tek numaralı olanlar ise yabancı para hesaplardır Yabancı para olarak belirtilen hesaplar, şirketlerin yabancı para işlemlerine ilişkin tutarların kaydedildiği hesaplardır. Bu hesaplardaki yabancı para bakiyeler ilgili Türkiye Muhasebe Standardı hükümleri çerçevesinde dönem sonlarında değerlemeye tabi tutularak değerleme farkları ilgili hesaplara intikal ettirilir. Yabancı para hesaplardan ve işlemlerden sağlanan yabanc1 para faiz, komisyon ve gelirler, işlem tarihindeki kurdan Türk parasına çevrilir ve ilgili yabancı para kâr/zarar hesaplarına kaydedilir. Yukarıda belirtilen gelirler, yabancı para yerine Türk parası üzerinden tahsil edilse bile, yabancı para kâr-zarar hesaplarına kaydedilir (BDDK, 2013).

Aşağıda yer alan finansal kiralama şirketlerinin finansal riskten korunma muhasebesi uygulaması durumundaki muhasebe kayıtlarını gösteren uygulama örneklerinin muhasebeleştirilmesi, Bankacılık Düzenleme ve Denetleme Kurumu tarafından yayımlanan Tekdüzen Hesap Planı doğrultusunda gerçekleştirilmiştir. Örneklerin oluşturulmasında, Bline, Ficher ve Skekel (2001), Ramirez (2007), ve Beams vd. (2012) referans alınmıştır.

\subsection{Gerçeğe Uygun Değer Riskinden Korunma Amaçlı Uygulama Örneği}

ZTM Finansal Kiralama şirketi 01.07.2016 günü A şirketinden $\$ 100.000$ tutarında idari bölüm için güvenlik sistemi makinesi satın almış, fakat henüz borcunu ödememiş ve ödeme tarihi olarak 30.09.2016 tarihi olarak anlaşmışlardır. ZTM Finansal Kiralama şirketi kurun yükseleceğini tahmin ettiğinden, döviz olarak da borcu bulunduğundan kurun artışından korunmak için opsiyon sözleşmesi satın almak istemektedir. ZTM finansal 
kiralama şirketi tarafindan 01.07.2016 tarihinde $\$ 1=3,00$ TL kuru üzerinden 30.09.2016 vadeli her biri $\$ 10.000$ 'dan olmak üzere 10 adet opsiyon sözleşmesi satın alınmıştır. Opsiyon primi, her $\$ 1$ için 0,030 \$TL dir ve 10 adet sözleşme için prim tutarı, $\$ 10.000$ x 10 adet $\mathrm{x}$ $0,030=3.000$ TL'dir. Kurlar:

01.07.2016: $\quad \$ 1=2,95 \mathrm{TL}$

30.09.2016: $\quad \$ 1=3,10 \mathrm{TL}$

-ZTM şirketinin malı satın alınması muhasebe kaydı:

$\$ 100.000 \times 2,95=295.000 \mathrm{TL}$

01.07.2016

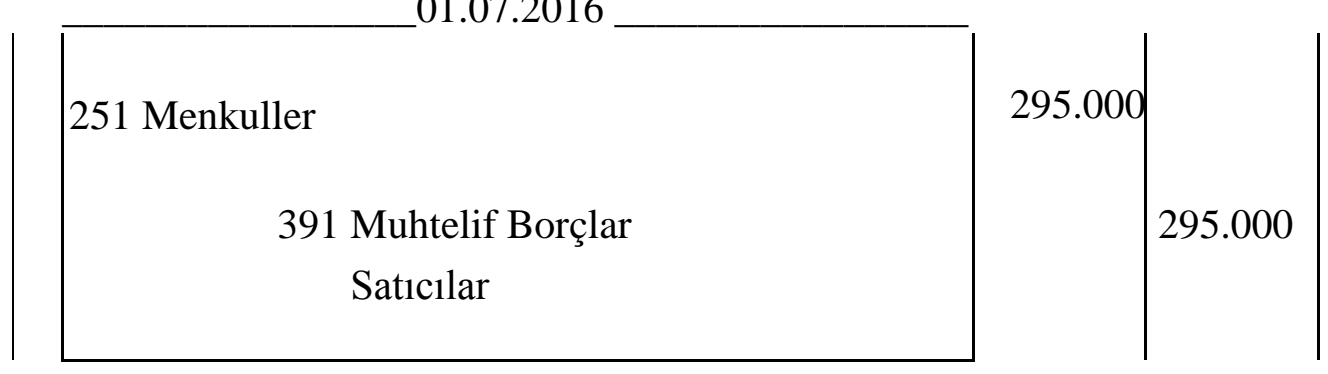

-ZTM şirketinin opsiyon sözleşmesinin nazım hesaplara muhasebe kaydı:

$\$ 10.000$ x 10 adet $\times 3,00=300.000 \mathrm{TL}$

01.07.2016

945 Riskten Korunma Amaçlı Türev Finansal

Araçlardan Alacaklar

947 Riskten Korunma Amaçlı Türev

Finansal Araçlardan Borçlar

-A firması opsiyon primine ait muhasebe kaydı:

$\$ 10.000$ x 10 adet x $0,030=3.000 \mathrm{TL}$

01.07.2016


$$
280 \text { Borçlu Geçici Hesaplar }
$$$$
3.000 \mid
$$ 
-Opsiyon priminin Temmuz ayı zaman değeri:

$3000 \mathrm{TL} \times 1 / 3=1.000 \mathrm{TL}$
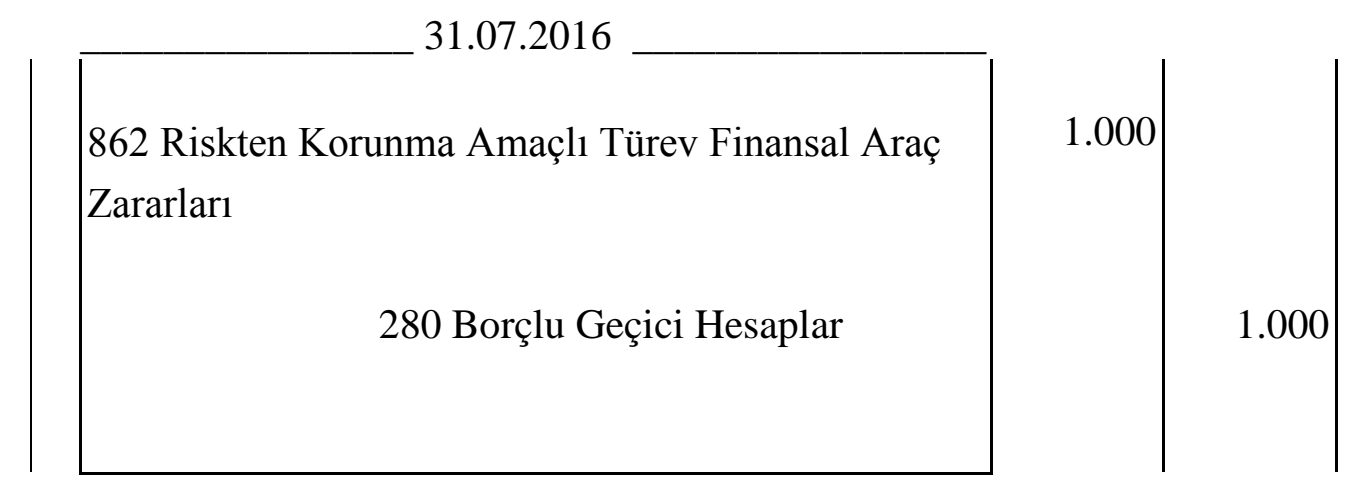

-Opsiyon priminin Ağustos ayı zaman değeri:

$3000 \mathrm{TL} \times 1 / 3=1.000 \mathrm{TL}$

31.08.2016
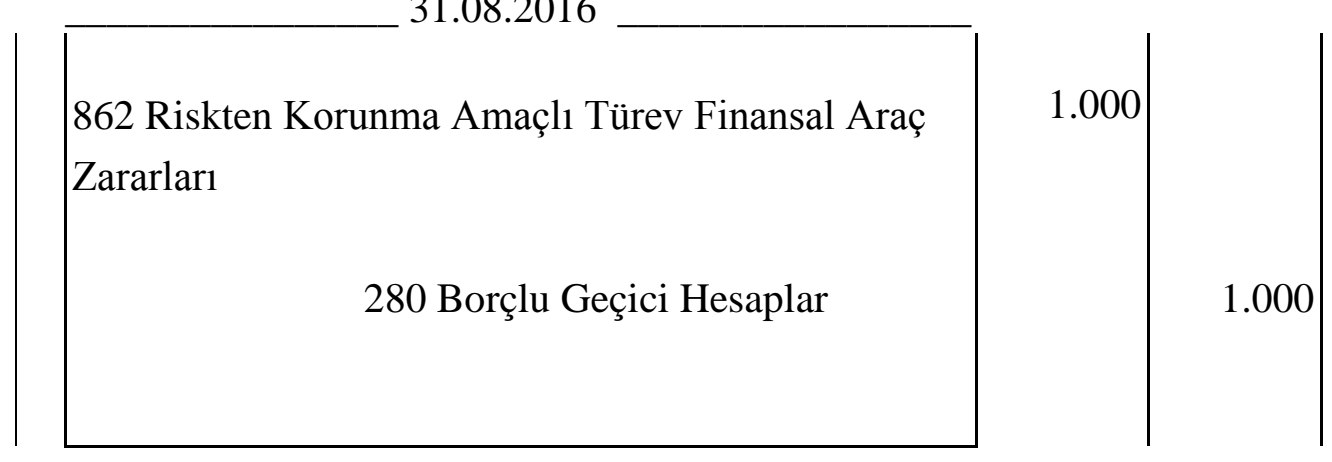

-30.09.2014 tarihindeki kur değişimi:

$\$ 10.000$ x 10 adet $\times(3,10-3,00)=10.000 \mathrm{TL}$

30.09.2016

225Türev Finansal Varlıklar

Finansal Araçlardan Kârlar 
-Opsiyon priminin Eylül ayı zaman değeri:

$3000 \mathrm{TL} \times 1 / 3=1.000 \mathrm{TL}$
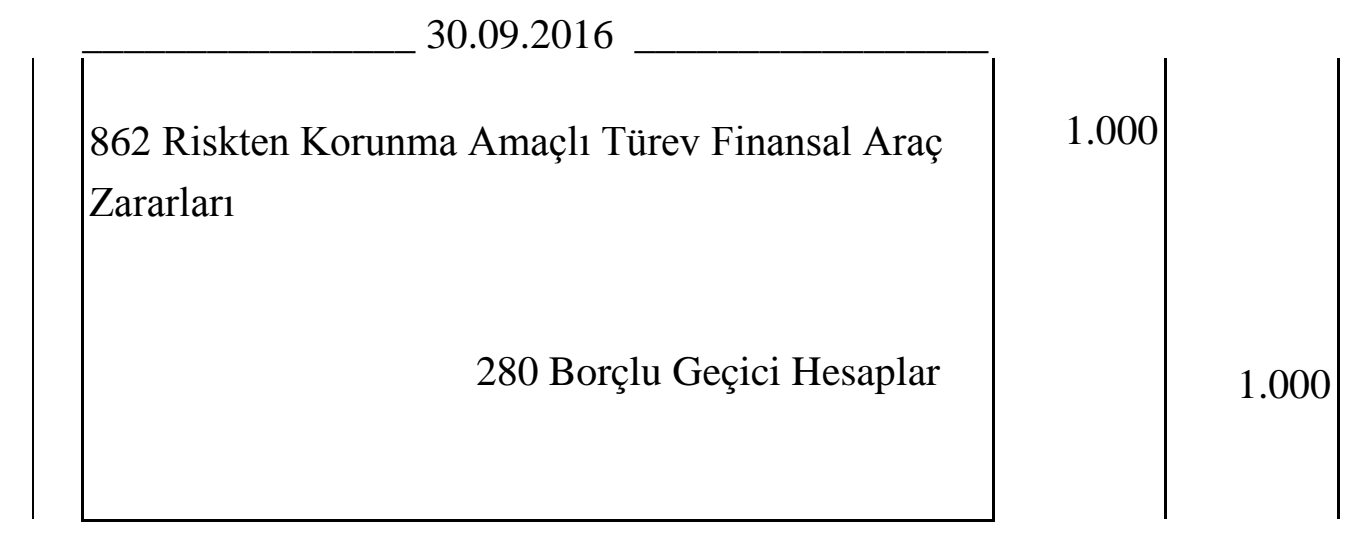

-ZTM Finansal kiralama şirketinin satıcıya olan borcunun kur farkı:

$\$ 100.000 \times(3,10-2,95)=15.000 \mathrm{TL}$

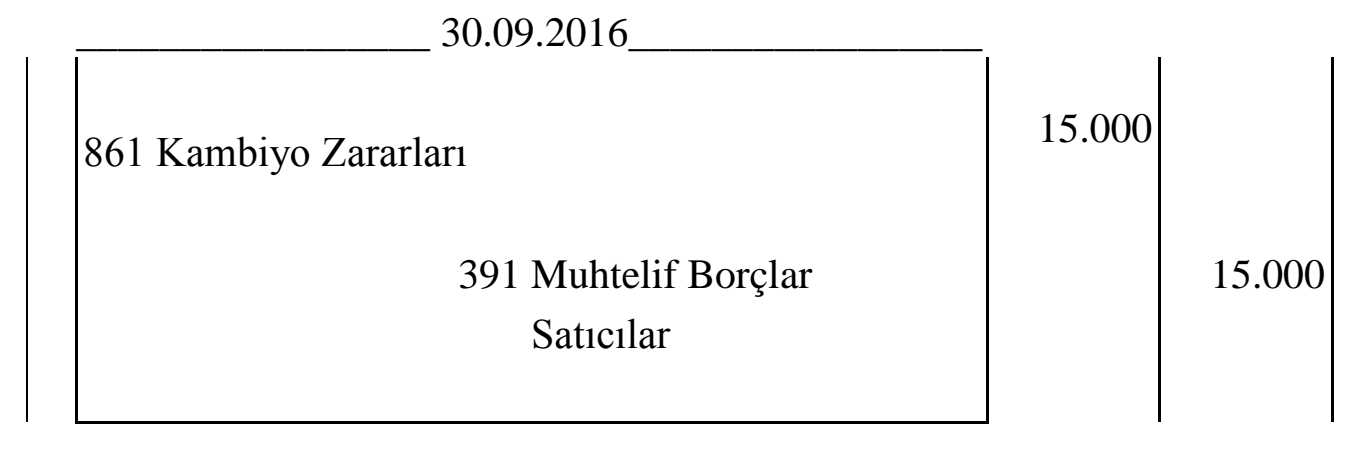

-30.09.2016 tarihinde opsiyon sözleşmenin sona erdirilmesi ve satıcıya borcun ödenmesi:

Opsiyon sözleşme piyasa fiyatı: $\$ 10.000$ x 10 adet x $3,10=310.000 \mathrm{TL}$

Opsiyon sözleşme bedeli

: $\$ 10.000 \times 10$ adet $\times 3,00=300.000 \mathrm{TL}$

Kur Fark1:

$\$ 10.000 \times 10$ adet $\times(3,10-3,00)=10.000 \mathrm{TL}$ 30.09.2016

\section{Muhtelif Borçlar}

Satıcilar 
-Nazım hesapların kapatılması:

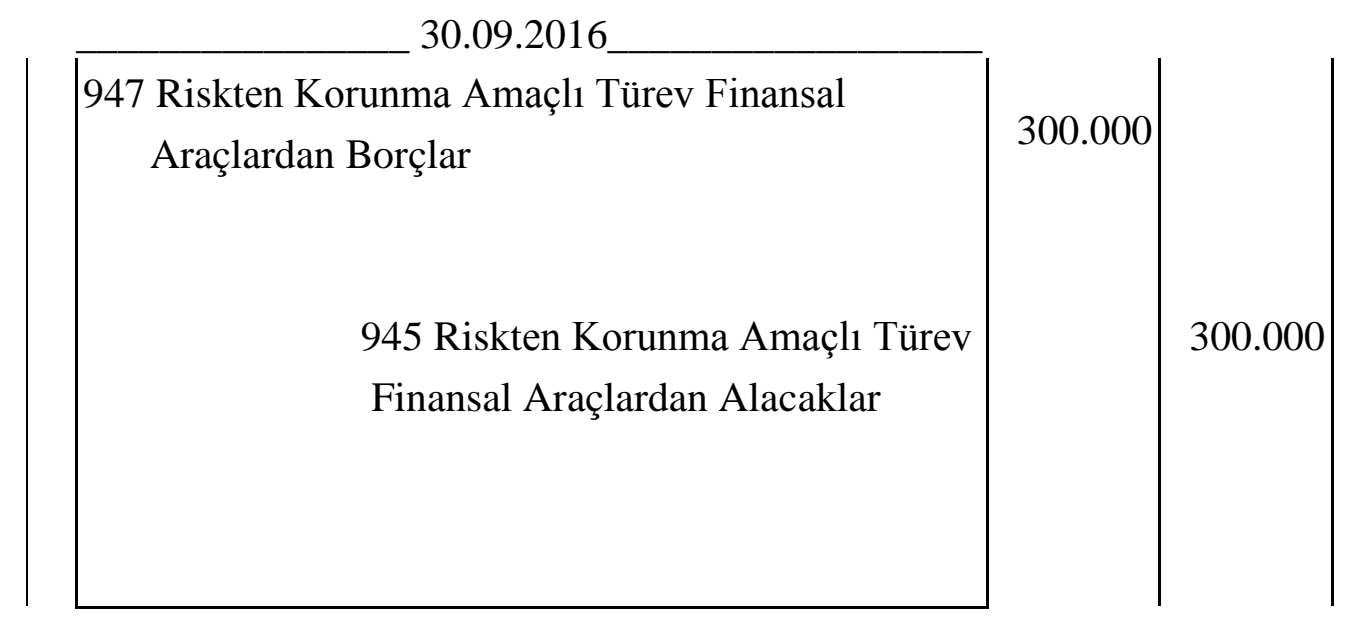

Yukarıdaki örnekte gerçeğe uygun değer riskinden korunma söz konusu olduğundan standartta belirtildiği üzere sermaye hesapları kullanılmayıp kâr zarar hesapları kullanmıştır.

\subsection{Nakit Akış Riskinden Korunma Amaçlı Uygulama Örneği}

ZTM Finansal Kiralama şirketi bilgisayar teçhizatı satın almak istemektedir. Bunun için yurt dışındaki C şirketi ile satın alım sözleşmesi imzalanmıştır. Sözleşme detayları aşağıdaki gibidir:

-Anlaşma tarihi: $\quad 01.01 .2016$

-Malın teslim tarihi: $\quad 31.07 .2016$

-Anlaşma tutarı: $\quad \$ 100.000$

-Anlaşma tarihindeki kur: $\$ 1=3,10 \mathrm{TL}$

ZTM Finansal Kiralama şirketi, 31.07.2016 tarihindeki \$100.000'l1k ödeme nedeniyle ortaya çıkacak riskten sakınabilmek amacıyla 01.01.2016 tarihinde $\$ 1=3,20$ TL kuru üzerinden futures sözleşme satın almıştır. Futures sözleşme nedeniyle 10.000 TL komisyon ödemiştir. Kurlar:

31.03.2016: $\$ 1=3,25 \mathrm{TL}$

30.06.2016: $\$ 1=3,27 \mathrm{TL}$

31.07.2016: $\$ 1=3,30 \mathrm{TL}$

-01.01.2016 tarihinde ZTM finansal kiralama şirketinin satın aldığ futures sözleşmesinin nazım hesaplara kaydı:

$\$ 100.000$ x 3,20 = 320.000 TL 
01.01.2016

\begin{tabular}{|c|c|c|}
\hline $\begin{array}{l}945 \text { Riskten Korunma Amaçlı Türev Finansal } \\
\text { Araçlardan Alacaklar }\end{array}$ & 320.000 & \\
\hline $\begin{array}{l}947 \text { Riskten Korunma Amaçlı Türev } \\
\text { Finansal Araçlardan Borçlar }\end{array}$ & & 320.000 \\
\hline
\end{tabular}

-01.01.2016 tarihindeki futures sözleşme için ödenen masrafların muhasebe kaydı: 01.01.2016

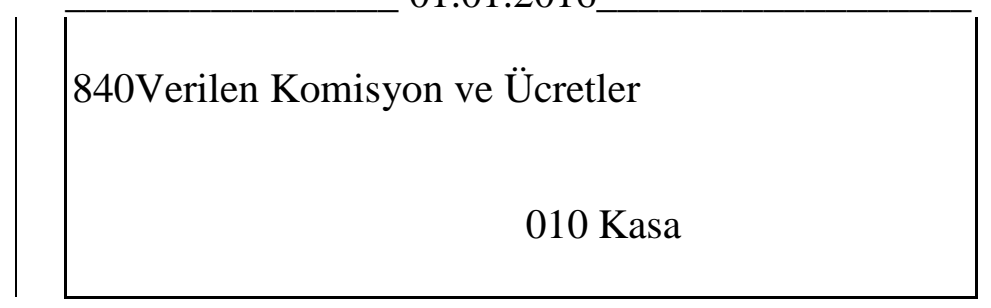
$10.000 \mid$

-31.03.2016 tarihindeki kur değişimi:

$\$ 100.000 \times(3,25-3,20)=5.000 \mathrm{TL}$
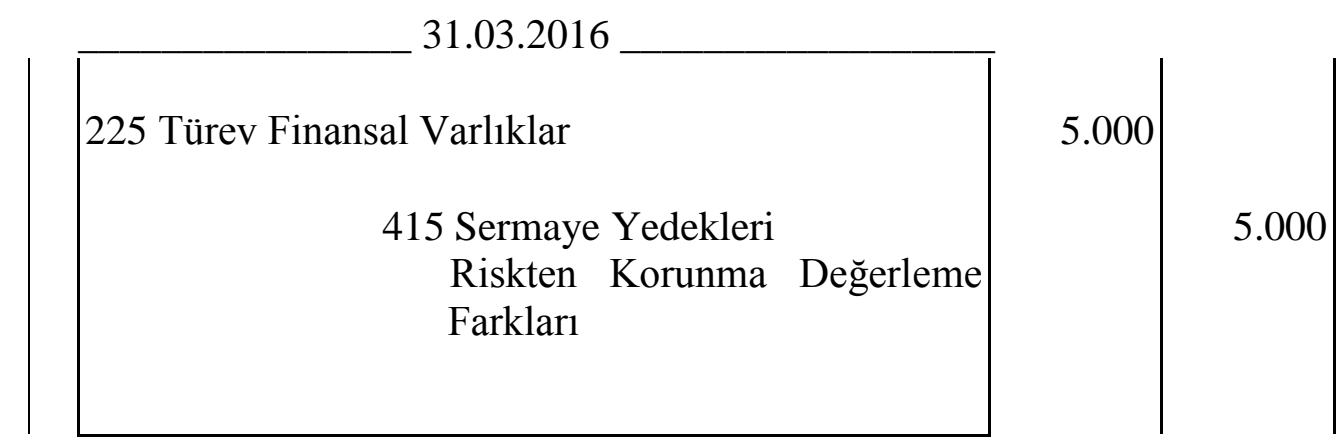

-30.06.2016 tarihinde kur değişimi:

$\$ 100.000 \times(3,27-3,25)=2.000 \mathrm{TL}$

30.06.2016

225 Türev Finansal Varlıklar

415 Sermaye Yedekleri

Riskten Korunma Değerleme

Farklar1 
-30.07.2016 tarihinde kur değişimi:

$\$ 100.000 \mathrm{x}(3,30-3,27)=3.000 \mathrm{TL}$ 31.07.2016
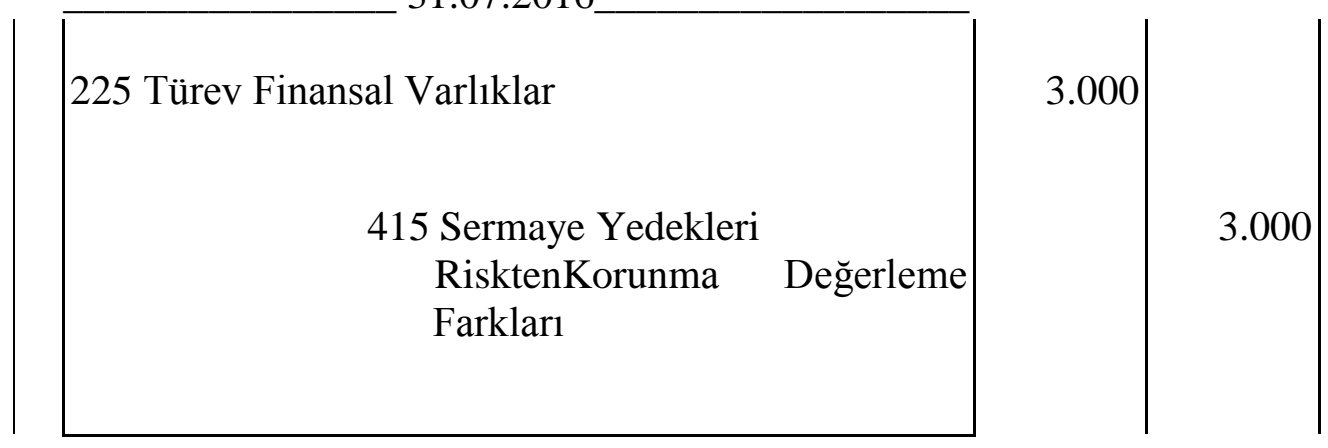

-C şirketinden malın satın alınması:

$\$ 100.000 \times 3,30=330.000 \mathrm{TL}$

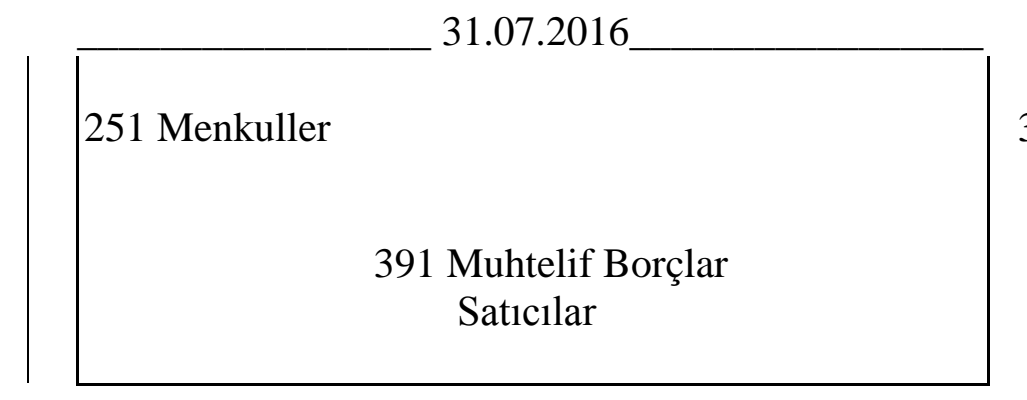

-31.07.2016 tarihinde futures sözleşmenin sona erdirilmesi:

Futures sözleşme piyasa fiyatı $\$ 100.000 \times 3,30=330.000 \mathrm{TL}$

Futures sözleşme bedeli $\quad \$ 100.000 \times 3,20=320.000 \mathrm{TL}$

Kur Fark1

$$
\$ 100.000 \times(3,30-3,20)=10.000 \mathrm{TL}
$$

31.07.2016

391 Muhtelif Borçlar

Saticilar 
-Nazım hesapların kapatılmasi:
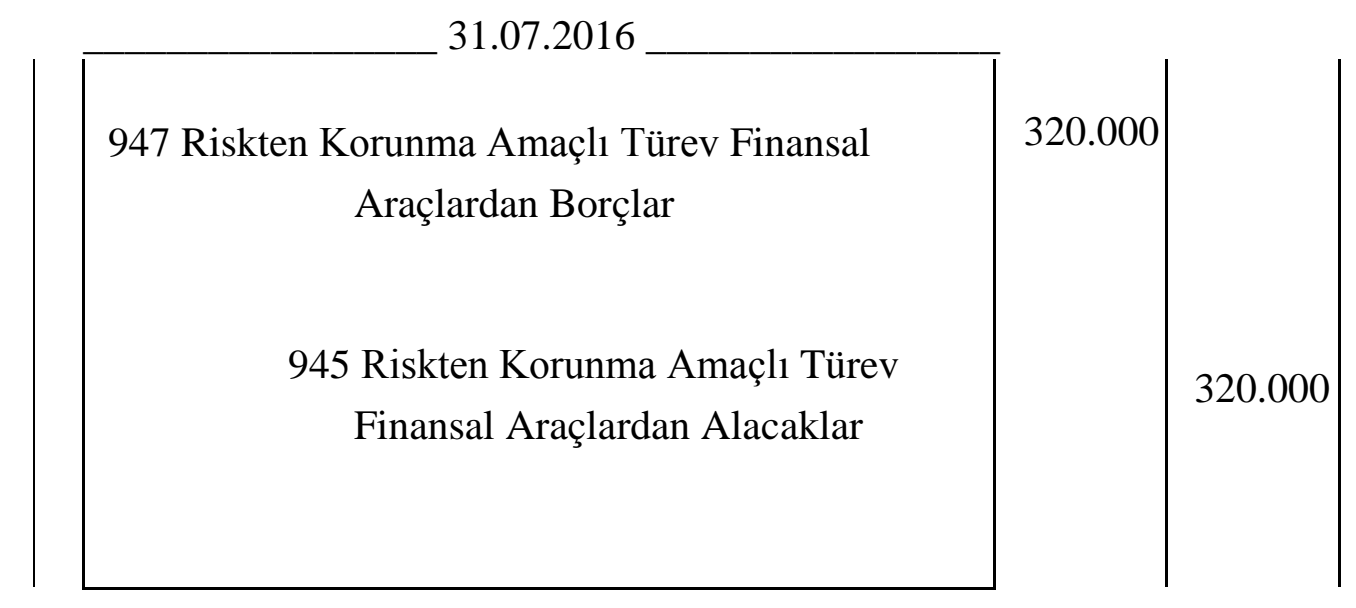

-Değerleme farkının kapatılması:

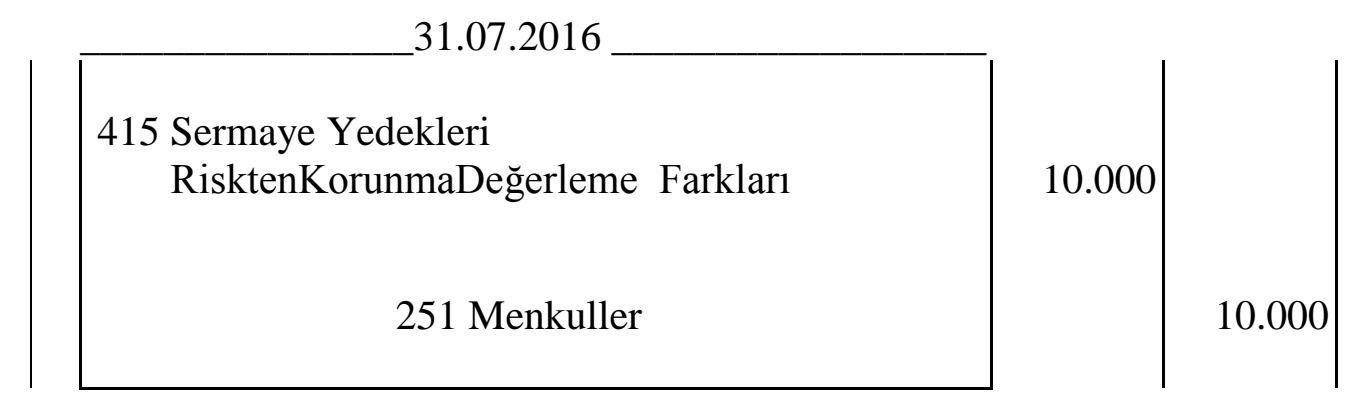

Türev araç ile ilgili oluşan ve özkaynaklarda raporlanan "415 Sermaye Yedekleri Riskten Korunma Değerleme Farkları" hesabının kapatılmasında kullanılan yöntemden biri de oluşan gerçeğe uygun değerleme farkları ilgili varlığın maliyetinden düşülebilmektedir. Yukarıdaki örnekte bu yöntem uygulanmaktadır.

\subsection{Net Yatırım Riskinden Korunma Amaçı Uygulama Örneği}

A Finansal kiralama şirketi 01.10.2015 tarihinde, Amerika'da faaliyet gösteren Z şirketinin \%30’unu \$100.000 ödeyerek 31.01.2016 tarihinde satın almak üzere anlaşmıştır. A finansal kiralama şirketi söz konusu yatırımı nedeniyle maruz kaldığı kur riskinden sakınmak için forward sözleşme satın alımını gerçekleştirmiştir. Forward sözleşme ayrıntıları:

Anlaşma tarihi: $\quad 01.10 .2015$

Bitiş tarihi : $\quad 31.01 .2016$

Forward kuru: $\quad \$ 1=2,80 \mathrm{TL}$

Anlaşma tutarı : $\quad \$ 100.000$

31.12.2015 tarihi kur: $\$ 1=2,90$ TL

31.01.2016 tarihi kur $\$ 1=2,85 \mathrm{TL}$ 
-01.10.2015 tarihinde A firmasının C bankası ile yaptığı forward sözleşmenin nazım hesaplara muhasebe kayd1: $\$ 100.000$ x 2,80=280.000 TL 01.10 .2015

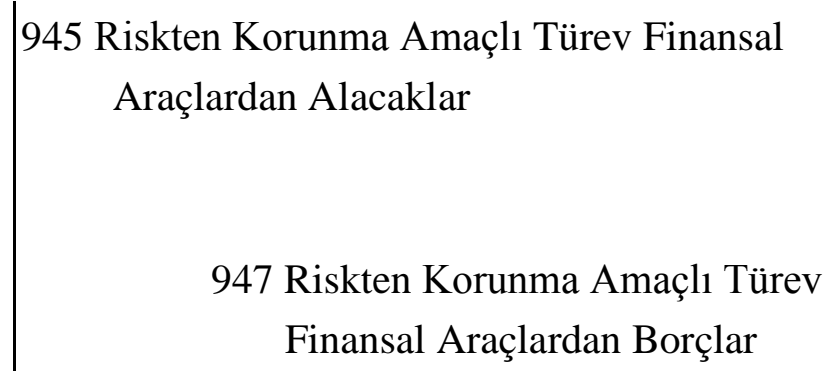

-31.12.2015 tarihinde kur değişiminin muhasebe kaydı:

$\$ 100.000 \times(2,90-2,80)=10.000 \mathrm{TL}$
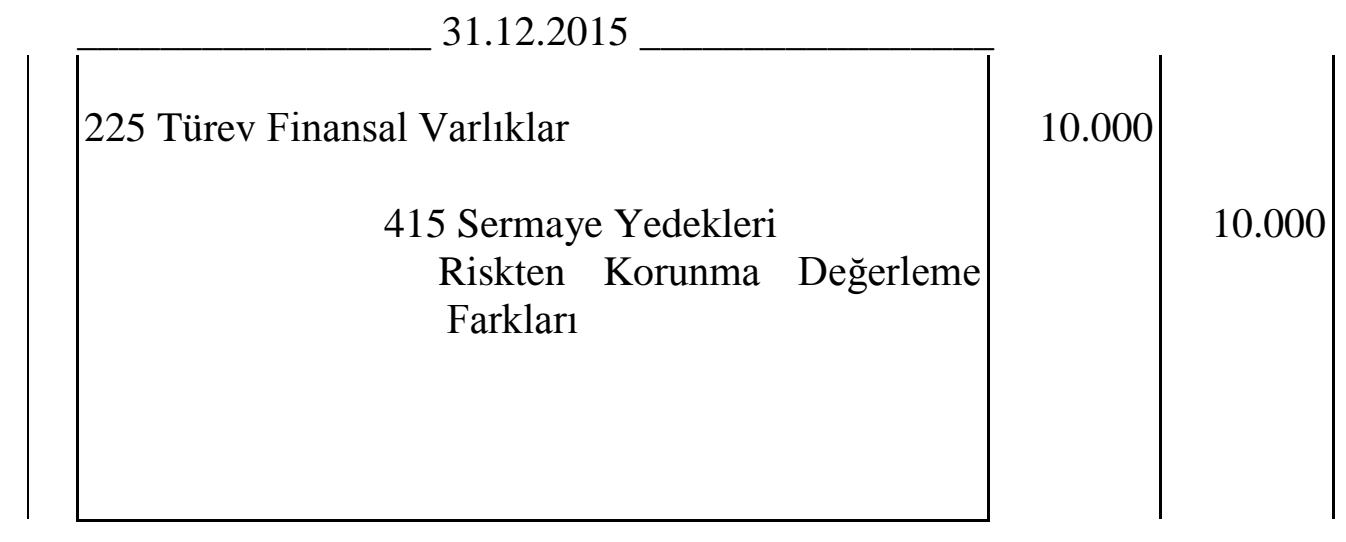

-31.01.2016 tarihinde kur değişiminin muhasebe kaydı:

$\$ 100.000 \times(2,85-2,90)=5.000 \mathrm{TL}$
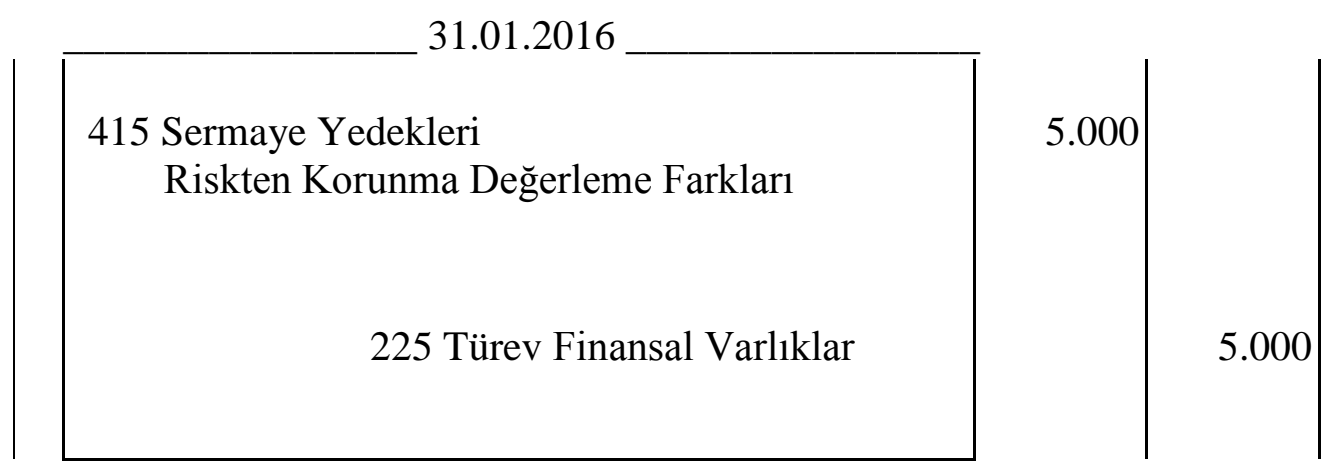
-31.01.2016 tarihinde forward sözleşmenin sona erdirilmesi:

Forward sözleşme bedeli $\$ 100.000$ x 2,80 = 280.000 TL

Forward piyasa bedeli $\quad \$ 100.000 \times 2,85=285.000 \mathrm{TL}$

Kur fark1

$\$ 100.000 \times(2,85-2,80)=5.000 \mathrm{TL}$

31.01 .2016
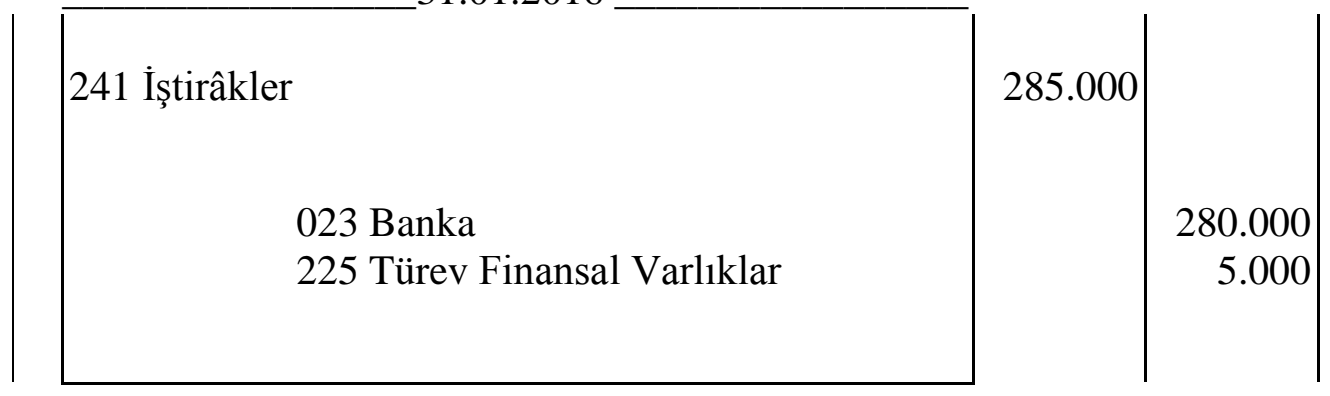

-Sözleşmenin sonlandırılması nedeniyle nazım hesapların kapatılmasının muhasebe kayd1:

31.01.2016

\begin{tabular}{|c|c|c|}
\hline $\begin{array}{l}947 \text { Riskten Korunma Amaçlı Türev Finansal } \\
\text { Araçlardan Borçlar }\end{array}$ & 280.000 & \\
\hline $\begin{array}{c}945 \text { Riskten Korunma Amaçlı Türev } \\
\text { Finansal Araçlardan Alacaklar }\end{array}$ & & 280.000 \\
\hline
\end{tabular}

-31.03.2016 tarihinde iştirâk ile ilgili kur farkı: (31.03.2016 \$kur:2,95)

Kur fark1 $\$ 100.000 \times(2,95-2,85)=5.000 \mathrm{TL}$

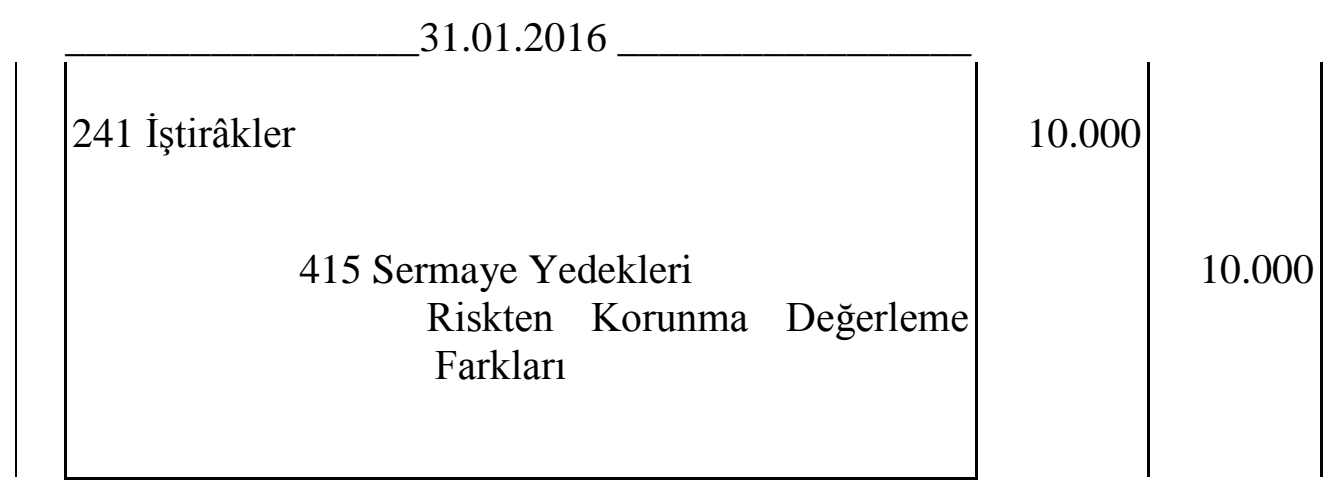


-31.03.2016 tarihinde A finansal kiralama şirketi Z şirketindeki $\$ 100.000$ 'l1k \%30 iştirâk tutarını $\$ 110.000$ olarak satmıştır. Satış ile ilgili bilgiler:

$\begin{array}{ll}\text { İştirâkin kayıtlardaki değeri } & : \$ 100.000 \times 2,95=295.000 \mathrm{TL} \\ \text { İştirâkin satış tutarı } & : \$ 110.000 \times 2,95=324.500 \mathrm{TL} \\ \text { Sermaye yedekleri hesap kalanı } & : 15.000 \mathrm{TL}\end{array}$
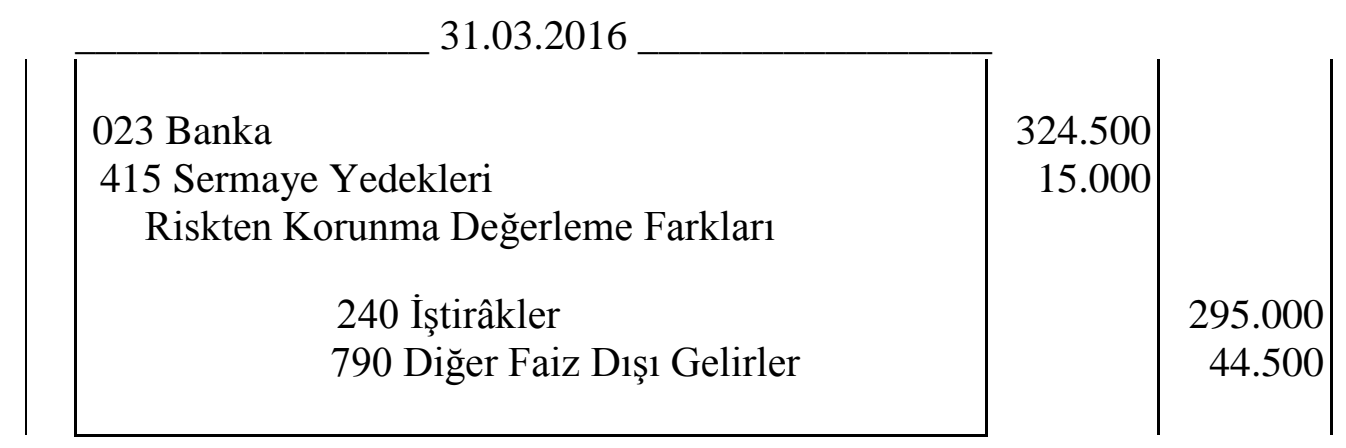

TMS 21 Standardına göre, iştirâk elden çıkarılana kadar oluşan kur farkları yine özkaynak hesaplarında izlenmeye devam edilmektedir. İştirâkin satılması ile birlikte özkaynak hesabı satışa ilişkin yevmiye maddesinde yer alarak hesap kapatılır.

\section{SONUÇ}

Finansal kiralama şirketleri, yatırımları ve milli geliri artırıcı etkisi ve ekonomiye ciddi anlamda katkısı sağlayan şirketlerdir. Finansal kiralama şirketleri Bankacılık Düzenleme ve Denetleme Kurulu (BDDK) tarafından Resmi Gazete'de yayımlanmış olan 6361 sayılı "Finansal Kiralama, Faktoring ve Finansman Şirketleri Kanunu "nu tabiidir.

Finansal kiralama şirketlerinin faaliyetlerinin muhasebeleştirmede, Bankacılık Düzenleme ve Denetleme Kurumu (BDDK) tarafından yayımlanmış ayrı bir Tekdüzen Hesap Planı (THP) kullanılmaktadır. Finansal kiralama şirketleri, muhasebe kayıtlarını ve finansal raporlarını Kamu Gözetimi, Muhasebe ve Denetim Standartları Kurumu tarafından yürürlüğe konulan Türkiye Muhasebe Standartları ile Türkiye Finansal Raporlama Standartları ve BDDK tarafından muhasebe ve raporlama esaslarına ilişkin yayımlanan yönetmelik ve tebliğler doğrultusunda gerçekleştirmektedir.

$\mathrm{Bu}$ çalışmanın amacı, Türkiye Muhasebe Standartlarına tabi olmasına rağmen muhasebe kayıtlarında ayrı bir hesap planının kullanıldığı finansal kiralama şirketlerinin riskten korunma muhasebesi uygulamalarına yer verilerek literatüre katkı sağlamaktır.

Türkiye Muhasebe Standartları ile Türkiye Finansal Raporlama Standartlarının yürürlüğe girmesiyle riskten korunma muhasebesi uygulaması gündemimizdedir. Riskten korunma muhasebesi uygulaması finansal kiralama şirketleri için de geçerlidir ve bazı istisnalar söz konusu olup, bunlarda biri de “TMS 17 Finansal Kiralama Standardı"nın uygulandığı faaliyetlerde riskten korunma uygulanmamaktadır. 
Finansal kiralama şirketlerinin muhasebe işlemlerinde kullandığı ve BDDK tarafindan 2013 yılında yayımlanan Tekdüzen Hesap Planı'nda yer alan hesaplar, işlemleri ayrıntılı bir şekilde kayıtlara aktarma özellikleri bakımından kullanışlıdır. Hesap planında belirtilen hesaplar, para birimi açısında Türk parası ve yabancı para şeklinde ayrılmıştır. Hesap planında bulunan hesaplarda riskten korunma muhasebesi uygulaması için gerekli hesaplar ayrıntılı olarak tanımlanmıştır. Riskten korunmanın çeşitleri açısından hesapların izlenmesine imkan sağlanmaktadır.

Çalışmada, gündemimize TMS/TFRS ile giren riskten korunma muhasebesinin finansal kiralama şirketleri tarafindan ne şekilde gerçekleştirildiği örnek uygulamalarla açıklanmıştır. Finansal kiralama şirketlerinin riskten korunma muhasebesine ilişkin muhasebe uygulama esasları ve kullanılacak hesaplar ortaya konulmuştur.

Gerçeğe uygun değer riskinden korunmada işlem süresince değerleme farkları kâr veya zarar hesaplarına, nakit akış riskinden ve net yatırım riskinden korunmada işlem süresince etkin kısımlar diğer kapsamlı gelirde, etkin olmayan kısımlar ise kâr veya zarar hesaplarına kaydedilmektedir. Finansal riskten korunma muhasebesi uygulaması ile riskten korunma aracından ve riskten korunma konusu kalemden kaynaklanan kâr veya zarar aynı dönemde muhasebeleştirilebilmekte ve aynı dönemde raporlanmayı sağlamaktadır.

Ekonomide çok önemli düzenleyici rol üstlenen ve bankalar yerine alternatif olarak tercih edilebilen finansal kiralama şirketlerinin muhasebe uygulamaları da önem teşkil etmektedir. Riskten korunma muhasebesi uygulamasında finansal kiralama şirketleri tarafından yapılması gereken muhasebe kayıtları literatürde fazla ele alınmadığından bu çalışmanın söz konusu yönüyle ilgili literatüre katkı sağlaması beklenmektedir. Gelecek çalışmalarda finansal kiralama şirketlerinin Türkiye Muhasebe Standartları çerçevesindeki işlemleri ve muhasebe kayıtlarının ele alınması önerilebilir.

\section{KAYNAKLAR}

Alphan, Fulya (1999), Örneklerle Futures Anlaşmalar ve Opsiyonlar, Literatür Yayınları, İstanbul.

Bankacılık Düzenleme ve Denetleme Kurumu, (2013). "Finansal Kiralama, Faktoring ve Finansman Şirketlerince Uygulanacak Tekdüzen Hesap Planı ve İzahnamesi Hakkında Tebliğ, 24 Aralık 2013 tarihli ve 28861 sayılı Resmi Gazete.

Beam, A.Floyd - Anthony, H. Joseph - Bettinghaus, Bruce - Smith, A. Kenneth (2012), Advanced Accounting, Eleventh Edition, Pearson Education, Inc, New Jersey.

Bline, M. Dennis, Ficher, L. Marry - Skekel, d. Ted (2001), Advanced Accounting, 8th Edition, South Western College, John Wiley \& Sons, Inc.

Ceylan, Ali (2003), Finansal Teknikler, 5. Baskı, Ekin Kitabevi, Bursa.

Demir, Volkan (2009), TFRS/UFRS Kapsamında Finansal Araçlar, Nobel Yayın, Ankara. 
Köksal, Ayşe Gül - Beller Beyhan (2013), "Finansal Kiralama İşlemlerinin TMS 17, Vergi Mevzuatı, BDDK Tebliği Açısından İncelenmesi ve Muhasebe Uygulamaları”, Niğde Üniversitesi, İ̈BF Dergisi, Cilt: 6, Say1: 2, s.150- 171.

Örten, Remzi - Kaval, Hasan - Karapınar Aydın (2014), Türkiye Muhasebe - Finansal Raporlama Standartları Uygulama ve Yorumları, 7.Baskı, Gazi Kitabevi, Ankara.

Ramirez, Juan (2007), Accounting For Derivatives: Advanced Hedging Under IFRS (The Wiley Finance Series), John Wiley \& Sons Ltd, England.

TMS 39 Finansal Araçlar: Muhasebeleştirme ve Ölçüm” Standard1, http://www.kgk.gov.tr/contents/files/TFRS_2015/TMS/TMS39.pdf, 15.02.2015. 
